\title{
Oviposition responses of aphidophagous coccinellids to tracks of ladybird (Coleoptera: Coccinellidae) and lacewing (Neuroptera: Chrysopidae) larvae
}

\author{
ZDENĚK RŮŽIČCKA \\ Institute of Entomology, Academy of Sciences, Branišovská 31, 37005 České Budějovice, Czech Republic, \\ e-mail: ruzicka@entu.cas.cz
}

Key words. Coccinellidae, Chrysopidae, Coccinella septempunctata, Cycloneda limbifer, Leis dimidiata, Semiadalia undecimnotata, Chrysopa oculata, Chrysopa perla, predators, aphidophagous insects, larvae, semiochemicals, oviposition-deterring tracks, intraspecific effects, interspecific effects, allomones, faeces

\begin{abstract}
The effects of oviposition-deterring larval tracks of four aphidophagous coccinellids and two chrysopids were investigated on females of four coccinellid species in choice tests. Aphidophagous coccinellids Cycloneda limbifer Casey, Semiadalia undecimnotata (Schneider) and Coccinella septempunctata L. laid significantly fewer eggs on sites with tracks of unfed conspecific first instar larvae than on clean sites, but Leis dimidiata (F.) laid similar numbers of eggs on both sites.

In some but not all species, tracks of heterospecific predators also deterred coccinellid females. Interspecific effects were stronger between some allopatric species than between the sympatric coccinellids $C$. septempunctata and $S$. undecimnotata. C. limbifer laid relatively few eggs on sites previously exposed to larvae of $S$. undecimnotata and L. dimidiata. $S$. undecimnotata avoided sites with tracks of $L$. dimidiata larvae. The two smaller species, $C$. limbifer and $S$. undecimnotata, laid considerably fewer eggs per batch than the larger coccinellids, C. septempunctata and L. dimidiata. C. limbifer and S. undecimnotata oviposited similar numbers of eggs on clean sites and sites with tracks of chrysopid larvae of the species Chrysopa oculata and Chrysopa perla. Females of C. septempunctata laid fewer eggs on sites previously exposed to larvae of $C$. oculata but not C. perla.

Densities of faecal spots of coccinellid females on clean substrates and substrates with tracks of predatory larvae differed significantly in only one choice test ( $C$. limbifer females exposed to tracks of $S$. undecimnotata larvae). This indicates that the presence of larval tracks affects where females lay eggs more than where they search.
\end{abstract}

\section{INTRODUCTION}

Larvae of aphidophagous coccinellids consume numerous aphids during their development. Therefore, females should avoid ovipositing in aphid colonies that might be depleted at the time when larvae hatch from eggs. One can predict therefore that females will reduce oviposition at sites where conspecifics or heterospecific competitive predators are already present. Such restraint in the ovipositional behaviour of females is likely to reduce cannibalism and predation of offspring.

Although considerable attention has been paid to the foraging behaviour of aphidophagous coccinellids (Dixon, 1959; Mills, 1982; Wratten, 1973, 1976) and to the interactions between ladybird larvae and adults (Hemptinne \& Dixon, 1991; Hemptinne et al., 1992; Hemptinne et al., 1993), spacing of predatory insects among prey resources has been attributed only to effects of physical encounters as described by Hassell et al. (1976). Marks (1977) reported that an individual larva of Coccinella septempunctata L. recognized and avoided sites with its own tracks, but was not deterred from searching at sites with tracks of conspecific larvae. However, several attempts to confirm these observations have been unsuccessful (Dixon in Ferran \& Dixon, 1993). Females of Adalia bipunctata (L.) laid fewer eggs when confined in small Petri dishes with conspecific larvae or adults, but laid slightly more eggs than the control females when exposed to the odour of larvae (Hemptinne et al., 1992). Because effects of larval tracks on females were not considered, the authors concluded that inhibition of egg laying is positively correlated with the rate of female encounter with larvae. Ferran \& Dixon (1993) stressed the lack of knowledge of coccinellid spacing among prey patches of different quality also in their review on foraging behaviour of ladybird larvae.

Doumbia et al. (1998, p. 21) stated mistakenly that the response of aphidophagous predators to nonvolatile molecules in the tracks left by conspecific larvae was described by Hemptinne et al. (1993). In fact, the tracks left by larvae or signalling molecules were not considered by Hemptinne and co-authors. On the contrary, Hemptinne et al. (1993, p. 453) reported that the presence of conspecific larvae in the Petri dish did not inhibit egg laying in C. septempunctata, while the presence of another female in the dish resulted in the complete inhibition of egg laying and a strong reduction in activity.

Oviposition-deterring effects of larval tracks on females of aphidophagous predators were discovered quite incidentally for the first time in green lacewings (Růžička, 1994). It was observed that semiochemical marks of abdominal secretion left by first instars of Chrysopa oculata Say soon after eclosion deterred conspecific females from oviposition. The effects of conspecific larval tracks have since been reported for chrysopids Chrysopa perla (L.) (Rủžička, 1996), Chrysopa commata (Kiss \& Ujhelyi) and Chrysoperla carnea (Stephens) (Růžička, 
1998), aphidophagous coccinellids, C. septempunctata (Růžička, 1997b), A. bipunctata (Doumbia et al., 1998) and the aphid-feeding cecidomyiid, Aphidoletes aphidimyza Rondani (Růžička \& Havelka, 1998). Oviposition-deterring semiochemicals (ODS) in tracks of predatory larvae are soluble in chloroform (Růžička, 1994; Doumbia et al., 1998) and water (Růžička, 1994; Růžička \& Havelka, 1998).

Highly mobile larvae of chrysopids and coccinellids use the tip of their abdomen as a pseudopod. The soft abdominal disc on the end of the tip marks a surface with adhesive oviposition-deterring secretions. The frequency of female contact with a network of oviposition-deterring tracks of competitive predatory larvae is likely to be higher than the frequency of female encounter with the larvae. This semiochemical mechanism enables females to reliably detect the presence of very small or hidden larvae overleaf, and thereby avoid ovipositing where prey is likely to become scarce due to predation and where older predators might attack their progeny.

Strong interspecific effects were reported for each of 12 heterospecific combinations among four chrysopid species (Růžička, 1998). In some cases, females responded to tracks of heterospecific larvae more than to tracks of conspecific larvae. Females of the coccinellid C. septempunctata also decreased oviposition on substrates with tracks of $C$. oculata larvae, but $C$. oculata female laid similar numbers of eggs on clean sites and on sites with tracks of C. septempunctata larvae (Rủžička, 1997b). In contrast to widespread interspecific effects between chrysopid species, tracks of the coccinellid A. bipunctata larvae had no deterrent effect on oviposition of C. septempunctata females, and tracks of C. septempunctata or Adalia decempunctata (L.) larvae had no deterrent effect on females of $A$. bipunctata (Doumbia et al., 1998).

Contrary to the results of Doumbia et al. (1998) and Yasuda et al. (2000), results of preliminary experiments in my laboratory indicated strong interspecific effects of ODS between some coccinellid species. When given a choice of substrates, $C$. limbifer laid considerably fewer eggs on substrates previously exposed to $S$. undecimnotata larvae, than on clean substrates. Consequently, the experiments reported here were carried out to determine if female response to conspecific and heterospecific larval tracks is a common phenomenon among aphidophagous species of Coccinellidae, as might be expected given the high probability of competition for aphid prey resources. A strong response of coccinellid females to larval tracks might exist especially between sympatric species, that have the same essential aphid prey. Two such coccinellid species, that occur in the Czech Republic, C. septempunctata and S. undecimnotata, (Hodek, 1960; Iperti, 1965) were studied here. In chrysopids, larval tracks deterred females of both sympatric and allopatric species (Růžička, 1998). Therefore, two sympatric local and two allopatric coccinellids species (not occurring in the Czech Republic) were used to study deterrent effects of larval tracks among coccinellids.
Because $C$. septempunctata females have been shown to avoid ovipositing on substrates with larval tracks of the chrysopid C. oculata (Růžička, 1997b), ovipositiondeterring effects of tracks of $C$. oculata and $C$. perla larvae on coccinellid females were also investigated. The latter chrysopid is sympatric with the coccinellids C. septempunctata and S. undecimnotata.

\section{MATERIAL AND METHODS}

Experiments were performed on Cycloneda limbifer Casey (origin in Cuba), Leis dimidiata (F.) (origin in south-eastern China), Chrysopa oculata Say (origin in Nova Scotia, Canada) and Chrysopa perla (L.) (origin in South Bohemia, Czech Republic) from cultures maintained in the laboratory for periods greater than one year, on P - F2 generations of Coccinella septempunctata L. collected at Boršov near České Budějovice (South Bohemia), in April 1999, and on F1-F6 generations of Semiadalia undecimnotata (Schneider) $[=$ Ceratomegilla undecimnotata (Schneider)] collected at Raná, near Louny (Czech Republic), in September 1998.

The selection of oviposition site was investigated in laboratory choice tests. The experimental design of the previous study on ODS in the aphidophagous coccinellid, C. septempunctata, (Rủžička, 1997b) was used also in this study. Clean paper substrate was presented to females for ovipositing simultaneously with paper substrate that had been previously exposed to larvae of one predatory species. Males were not present in the tests. In blank tests, two clean paper strips were presented to females of each coccinellid species for ovipositing.

Contamination of paper substrates by coccinellid or chrysopid larvae. Two pieces of white paper, each $20 \mathrm{~cm}$ long and $4 \mathrm{~cm}$ wide, were folded transversely every $10 \mathrm{~mm}$ to create strips of total length of $13 \mathrm{~cm}$. These strips were exposed to 40 unfed first-instar larvae of one predatory species for 4 hours on the bottom of a glass Petri dish, $18 \mathrm{~cm}$ in diameter. The inner wall of the dish was painted with Fluon to keep the larvae inside the dish.

Choice test with coccinellid females. Each choice test was carried out in a cylindrical cage with 10 mated females, 15-35 days old. The cage was made of firm netting, $18 \mathrm{~cm}$ in diameter and $10 \mathrm{~cm}$ high. It was placed on a glass lid of a Petri dish and covered by an identical lid. Drinking water was provided and a surplus (2,5-4 thousand) of suitable aphids (Aphis fabae Scopoli for C. limbifer and Acyrthosiphum pisum Harris for the other coccinellid species) was available as prey. $A$. pisum was offered without the host plant, Vicia faba, whereas $A$. fabae was offered on shoots of the plants, because it could not be easily harvested from the plants. All experiments were done at $24 \pm 2{ }^{\circ} \mathrm{C}$ and $18 \mathrm{~L} / 6 \mathrm{D}$ photoperiod. White-light fluorescent tubes served as a light source.

The oviposition arena consisted of 2 parallel folded paper strips, symmetrically spaced $50 \mathrm{~mm}$ apart on the glass bottom. One strip was clean, the other was contaminated with larval tracks. The strips were provided for oviposition immediately after the contamination with larval tracks, with sides arranged in the same position as during the exposure to larvae. Intra- and interspecific effects of larval tracks of each predator on oviposition site selection by females of each coccinellid species were studied by recording the numbers of eggs laid on the clean and contaminated substrate. Numbers of faecal spots left by females on each substrate were also counted to assess whether tracks of larvae might repel females from searching on contaminated sites. Each choice test lasted 20 hours and was repeated ten times. 
To exclude possible preference of one side of the cage for egg laying by females, e.g. due to differences in light intensity, radiation of temperature or effects of geomagnetism, clean strips were placed in five replicates on the right semicircle sector of the glass bottom and in the other five replicates on the left semicircle sector.

Statistical analysis.Differences between numbers of eggs laid on expos ed and non-exposed paper strips were analysed with the Wilcoxon paired sample test. The same test was used to analyse differences between numbers of faecal spots excreted by coccinellid females on paper strips.

\section{RESULTS}

Oviposition on and outside strips in experimental cages

In blank tests, all coccinellid species laid similar numbers of eggs on two clean paper substrates (Table 1). In all tests, females rarely laid eggs on substrate other than the folded paper strips, and laid eggs almost exclusively on the lower side of the strips: C. limbifer laid $99.2 \%$ of eggs $(\mathrm{n}=22046)$, S. undecimnotata $99.95 \%$ eggs $(\mathrm{n}=$ 17543), L. dimidiata $99.97 \%$ eggs $(\mathbf{n}=23335)$ and $C$. septempunctata $100 \%$ eggs $(\mathrm{n}=27702)$ on the lower side $(\mathbf{n}=$ total number of eggs on paper strips in all experiments and one blank test). The two smaller coccinellid species, $C$. limbifer and $S$. undecimnotata, laid eggs in significantly smaller batches $(16.3 \pm 0.4, \mathrm{n}=254$, and $13.5 \pm 0.5, \mathrm{n}=231$ ) than two larger coccinellids, C. septempunctata and L. dimidiata, $(29.4 \pm 1.2, \mathrm{n}=158$, and $33.4 \pm 1.3, \mathbf{n}=120)$ (eggs/batch $\pm \mathrm{SE}, \mathrm{n}=$ number of batches in blank tests); ANOVA, $(\mathrm{P}<0.0001)$.

\section{Effects of tracks of conspecific coccinellid larvae}

Females of C. limbifer, S. undecimnotata and C. septempunctata laid significantly fewer eggs on substrates previously exposed to conspecific larvae than on clean substrates $(\mathrm{P}=0.0039, \mathrm{P}=0.0137$ and $\mathrm{P}=0.0137$ respectively). However, L. dimidiata laid similar numbers of eggs on these substrates (Table 1).

\section{Effects of tracks of heterospecific coccinellid larvae}

Females of C. limbifer laid significantly fewer eggs on substrates previously exposed to larvae of $S$. undecimnotata and $L$. dimidiata than on clean substrates $(\mathrm{P}=0.0020$ and $\mathrm{P}=0.0488$ ), but their oviposition was not deterred on substrates previously exposed to $C$. septempunctata larvae (Table 1). Females of S. undecimnotata laid significantly fewer eggs on sites with tracks of $L$. dimidiata larvae $(\mathrm{P}=0.0039)$. The presence of tracks of heterospecific coccinellid larvae did not deter females of C. septempunctata and $L$. dimidiata from ovipositing.

\section{Effects of tracks of chrysopid larvae}

The presence of tracks of chrysopid larvae did not deter females of C. limbifer, S. undecimnotata and L. dimidiata from ovipositing (Table 1). Females of C. septempunctata laid significantly fewer eggs on substrates with tracks of C. oculata larvae (but not of C. perla larvae) than on clean ones $(\mathrm{P}=0.0371)$.

\section{Effects of larval tracks on distribution of faecal spots}

The numbers of faecal spots on clean substrates and on substrates with tracks of larvae differed significantly only in the choice tests using $C$. limbifer females exposed to tracks of $S$. undecimnotata larvae $(\mathrm{P}=0.0020)$. In this single case, more faecal spots were deposited on clean paper strips than on contaminated substrates (Table 1).

\section{DISCUSSION}

To avoid possible counteractive effects of semiochemicals associated with aphid prey in this study, all substrates were exposed only to first instar coccinellid larvae which had not fed on aphids. Volatile semiochemicals of both aphid prey, and conspecific predators attracted larvae and adults of C. septempunctata in olfactometer tests (Sengonca \& Liu, 1994).

In choice tests, aphids $A$. pisum and $A$. fabae were distributed evenly on both substrates. In separate tests, $A$. pisum did not reveal statistically significant preference for one versus the other substrates when coccinellid females were not present ( $Z$. Růžička, unpublished data). Thus differences in numbers of eggs laid by coccinellids on the two substrates (clean and contaminated) were not the result of differences in prey numbers between substrates.

Although paper substrate with ODS of chrysopid larvae deterred conspecific females for many days (Růžička, 1997a), oviposition-deterring effects of tracks of unfed first instars of C. septempunctata on conspecific females decreased considerably within 24 hours following the exposure to larvae (Růžička, 1997b). Therefore, contaminated substrates in this study were provided for oviposition within 15 minutes after exposure to larvae.

Intraspecific oviposition-deterring effect of tracks of $C$. septempunctata was weaker in the population from South Bohemia studied here than in the previously studied population of this species from North Bohemia (Růžička, 1997b). The distance between localities for these two populations is $170 \mathrm{~km}$. In choice tests of the same design, the difference in percentages of eggs laid on uncontaminated substrates by females from North Bohemia and females from South Bohemia was significant (t-test on aresine transformed data, $\mathrm{P}=0.0024, \mathrm{t}=3.528$ ). This difference may be associated with geographical variability of intraspecific effects of tracks on C. septempunctata, as flexible response of females to larval tracks might be an adaptive characteristic of this successful predator. To confirm or reject geographical variability, however, effects of conspecific tracks within each population of $C$. septempunctatata, as well as effects of tracks of larvae from one population on females of the other population, should be compared simultaneously.

The occurrence of oviposition-deterring response to heterospecific semiochemicals is expected in competitive predatory insect species. However, in comparison with high incidence of intraspecific effects, interspecific effects of semiochemicals have been reported less frequently in insects. Interspecific effects have been described in bark beetles (Birch et al., 1980; Byers, 1993; Byers \& Wood, 1980; Byers et al., 1984), pyralids (Thiery \& Gabel, 1993), parasitoids (Janssen et al., 1995a,b) and also in predators recently (Růžička, 1996, 1997b, 1998; Růžička \& Havelka 1998). 
Table 1. Mean number (per replicate; SE in brackets) and mean percentage of eggs laid and faeces left by females of four coccinellid species (Semiadalia undecimnotata, Leis dimidiata, Cycloneda limbifer, Coccinella septempuctata) on clean substrates (-) and on substrates with tracks $(+)$ of first instar larvae of the same species and two chrysopid species (Chrysopa oculata, Chrysopa perla) in choice tests. 10 females of each species were tested in ten replicates. Numbers of eggs and fecal spots on substrates were compared with Wilcoxon paired sample test, * $=$ $\mathrm{P}<0.05 ; * *=\mathrm{P}<0.01 ; \mathrm{ns}=$ not significantly different $(\mathrm{P} \geq 0.05)$

\begin{tabular}{|c|c|c|c|c|c|c|c|c|c|c|c|c|c|c|}
\hline \multirow{3}{*}{ Females tested } & \multicolumn{8}{|c|}{ Coccinellid larvae tested } & \multicolumn{4}{|c|}{ Chrysopid larvae tested } & & \\
\hline & \multicolumn{2}{|c|}{ C. limbifer } & \multicolumn{2}{|c|}{ S. undecimnotata } & \multicolumn{2}{|c|}{ C. septempunctata } & \multicolumn{2}{|c|}{ L. dimidiata } & \multicolumn{2}{|c|}{ C. oculata } & \multicolumn{2}{|c|}{ C. perla } & \multicolumn{2}{|c|}{ Blank test } \\
\hline & - & + & - & + & - & + & - & + & - & + & - & + & - & - \\
\hline \multicolumn{15}{|l|}{ C. limbifer } \\
\hline eggs (SE) & $200(21)^{* *}$ & $33(13)$ & $276(20) \div *$ & $38(12)$ & $174(30) \mathrm{ns}$ & $151(32)$ & $230(35) * *$ & $91(33)$ & $157(24) \mathrm{ns}$ & $125(20) \mathrm{ns}$ & $140(24) \mathrm{ns}$ & $177(25)$ & $204(29) \mathrm{ns}$ & $209(20)$ \\
\hline$\%$ eggs laid & 86 & 14 & 88 & 12 & 56 & 43 & 73 & 27 & 56 & 43 & 44 & 56 & 48 & 52 \\
\hline faeces (SE) & $64(19) \mathrm{ns}$ & $67(4)$ & $84(8) \div *$ & $29(3)$ & $76(10) \mathrm{ns}$ & $65(7)$ & $61(6) \mathrm{ns}$ & $55(5)$ & $59(7) \mathrm{ns}$ & $47(6)$ & $70(8) \mathrm{ns}$ & $72(8)$ & $75(16) \mathrm{ns}$ & $71(6)$ \\
\hline$\%$ faeces & 49 & 51 & 73 & 27 & 53 & 47 & 52 & 48 & 55 & 45 & 50 & 50 & 52 & 48 \\
\hline \multicolumn{15}{|l|}{ S. undecimnotata } \\
\hline eggs (SE) & $149(25) \mathrm{ns}$ & $59(18)$ & $180(27) * *$ & $49(20)$ & $150(21) \mathrm{ns}$ & $85(17)$ & $212(24) \div$ & $16(14)$ & $122(23) \mathrm{ns}$ & $144(25)$ & $137(17) \mathrm{ns}$ & $138(14)$ & $156(20) \mathrm{ns}$ & $156(25)$ \\
\hline$\%$ eggs & 70 & 30 & 80 & 20 & 63 & 37 & 93 & 7 & 45 & 55 & 49 & 51 & 49 & 51 \\
\hline faeces (SE) & $103(11) \mathrm{ns}$ & $83(9)$ & $111(8) \mathrm{ns}$ & $101(9)$ & $71(6) \mathrm{ns}$ & $74(5)$ & $109(12) \mathrm{ns}$ & $92(13)$ & $80(6) \mathrm{ns}$ & $83(9)$ & $96(9) \mathrm{ns}$ & $100(11)$ & $85(8) \mathrm{ns}$ & $88(10)$ \\
\hline$\%$ faeces & 55 & 45 & 53 & 47 & 49 & 51 & 55 & 45 & 49 & 51 & 51 & 49 & 49 & 51 \\
\hline \multicolumn{15}{|c|}{ C. septempunctata } \\
\hline eggs (SE) & $196(27) \mathrm{ns}$ & $191(23)$ & $167(15) \mathrm{ns}$ & $205(33)$ & $367(30)=$ & $208(32)$ & $236(23) \mathrm{ns}$ & $185(39)$ & $188(29)=$ & $120(14)$ & $183(24) \mathrm{ns}$ & $124(21)$ & $192(28) \mathrm{ns}$ & $209(30)$ \\
\hline$\%$ eggs laid & 50 & 50 & 47 & 53 & 64 & 36 & 59 & 41 & 59 & 41 & 61 & 39 & 49 & 51 \\
\hline faeces (SE) & $95(11) \mathrm{ns}$ & $94(9)$ & $67(11) \mathrm{ns}$ & $70(12)$ & $98(10) \mathrm{ns}$ & $100(12)$ & $103(13) \mathrm{ns}$ & $85(9)$ & $89(7) \mathrm{ns}$ & $98(10)$ & $92(11) \mathrm{ns}$ & $76(12)$ & $76(11) \mathrm{ns}$ & $73(9)$ \\
\hline$\%$ faeces & 50 & 50 & 49 & 51 & 50 & 50 & 53 & 47 & 48 & 52 & 56 & 44 & 50 & 50 \\
\hline \multicolumn{15}{|l|}{ L. dimidiata } \\
\hline eggs (SE) & $151(26) \mathrm{ns}$ & $154(21)$ & $137(22) \mathrm{ns}$ & $93(26)$ & $128(22) \mathrm{ns}$ & $147(19)$ & $173(22) \mathrm{ns}$ & $109(27)$ & $230(26) \mathrm{ns}$ & $173(24)$ & $191(21) \mathrm{ns}$ & $181(26)$ & $204(27) \mathrm{ns}$ & $261(39)$ \\
\hline$\%$ eggs laid & 49 & 51 & 61 & 39 & 46 & 54 & 63 & 37 & 58 & 42 & 50 & 50 & 46 & 54 \\
\hline faeces (SE) & $56(7) \mathrm{ns}$ & $57(8)$ & $28(4) \mathrm{ns}$ & $34(5)$ & $32(4) \mathrm{ns}$ & $41(6)$ & $44(8) \mathrm{ns}$ & $43(5)$ & $58(6) \mathrm{ns}$ & $63(5)$ & $40(9) \mathrm{ns}$ & $36(6)$ & $62(7) \mathrm{ns}$ & $55(7)$ \\
\hline$\%$ faeces & 50 & 50 & 45 & 55 & 46 & 54 & 49 & 51 & 47 & 53 & 50 & 50 & 53 & 47 \\
\hline
\end{tabular}


In contrast to results of Doumbia et al. (1998) and Yasuda et al. (2000), results of this study show that coccinellid females are able to respond to tracks of heterospecific coccinellid larvae. However, tracks of larvae of the four coccinellid species tested deterred heterospecific coccinellid females in only 3 of 12 tested combinations. C. limbifer and $S$. undecimnotata, the two species that were deterred from ovipositing by the presence of larval tracks of heterospecific coccinellids, laid considerably smaller egg batches than C. septempunctata and $L$. dimidiata. As with chrysopids, there was no indication of stronger interspecific effects in species with similar geographical distribution. The geographical distributions of two coccinellid species examined in this study (C. septempunctata and $S$. undecimnotata) overlap, and the responses of these species to tracks of each other's larvae were not significant. On the other hand, females of $S$. undecimnotata avoided ovipositing at sites with larval tracks of the allopatric species $L$. dimidiata.

Although C. septempunctata females did not reduce oviposition at sites with heterospecific tracks of coccinellid larvae, females of this species significantly reduced oviposition at sites with tracks from larvae of the chrysopid $C$. oculata. Furthermore, similar responses of C. septempunctata to larval tracks from C. oculata were observed in a population collected in North Bohemia (Rủžička, 1997b). Tracks of aggressive larvae of both chrysopid species did not deter females of the smaller coccinellids, $C$. limbifer and $S$. undecimnotata, or females of the largest coccinellid, L. dimidiata, from ovipositing.

Results of this study demonstrate that females of different coccinellid species vary in their response to larval tracks of a particular predatory species. Therefore, larvae of different aphidophagous species evidently mark their tracks with either different ODS, or different mixtures of these semiochemicals.

The oviposition-deterring effect of larval tracks on conspecific and heterospecific females might result from females avoiding searching where tracks are present. Assuming that the amount of faeces excreted by coccinellid females on a substrate is positively correlated with the length of time spent on the substrate, I compared the number of faecal spots on clean and contaminated substrates to test for this nonspecific repellent effect of larval tracks on females. The difference between number of faecal spots on clean and contaminated substrates was statistically significant in only 1 of 24 tested combinations (females of four coccinellid species larvae of four coccinellid and two chrysopid species), and in only 1 of the 7 combinations in which statistically significant differences between numbers of eggs on clean and contaminated substrates were observed. Thus it does not appear that the reduced oviposition in these cases simply resulted from females spending less time on strips with larval tracks.

C. limbifer and $L$. dimidiata have been considered for aphid control in greenhouses (Zelený, 1969; Semyanov, 1998). New information on the range of responses in females of these species to tracks of conspecific and het- erospecific coccinellid and chrysopid larvae contributes to our knowledge on semiochemical spacing of aphidophagous predators over prey patches of different quality, and might be also employed to improve methods of the use of these beneficial insects in biological control of aphids. Results may be especially useful for timing releases when both coccinellid species will be employed together or with releases of chrysopids.

ACKNOWLEDGEMENTS. This research was supported by a grant from the Grant Agency of the Czech Republic, No. 206/00/0809, from the Entomology Institute project Z5007907 (Acad. Sci. CR) and the grant project S5007102 (Grant Agency Acad. Sci. CR) . I thank M. Cervenská and R. Guttwirthová for their assistance with experiments and cultures of insect. I am indebted to O. Nedvěd, D. Rủžička, V. Semyanov and J. Zelený for the collection and delivery of predators. I am indebted to A. Bezděk and R. Zemek for advice in statistic evaluation of results and, in particular, to anonymous referees for valuable suggestions and comments on the manuscript.

\section{REFERENCES}

Birch M.C., Svihra P., Paine T.D. \& Miller J.C. 1980: Influence of chemically mediated behavior on host tree colonization by four cohabiting species of bark beetles. J. Chem. Ecol. 6: 395-414.

BYers J.A. 1993: Avoidance of competition by spruce bark beetle species, Ips typographus and Pityogenes chalcographus. Experientia 49: 272-275.

Byers J.A. \& Wood D.L. 1980: Interspecific inhibition of the response of the bark beetle, Dendroctomus brevicomis and Ips paraconfusus to their pheromones in the field. J. Chem. Ecol. 6: $149-164$

Byers J.A., Wood D.L., Craig J. \& Hendry L.B. 1984: Attaractive and inhibitory pheromones produced in the bark beetle, Dendroctomus brevicomis, during host colonization: regulation of inter- and intraspecific competition. J. Chem. Ecol. 10: 861-877.

Dixon A.F.G. 1959: An experimental study of the searching behaviour of the predatory coccinellid beetle Adalia decempunctata (L.). J. Anim. Ecol. 28: 259-281.

Doumbia M., Hemptinne J.-L. \& Dixon A.F.G. 1998: Assessment of patch quality by ladybirds: role of larval tracks. Oecologia 113: 197-202.

Ferran A. \& Dixon A.F.G. 1993: Foraging behaviour of ladybird larvae (Coleoptera: Coccinellidae). Eur. J. Entomol. 90: $383-402$.

Hassell M.P., Lawton J.H. \& Beddington J.R. 1976: The components of arthropods predation. I. The prey death-rate. $J$. Anim. Ecol. 45: 135-164.

Hemptinne J.-L. \& Dixon A.F.G. 1991: Why ladybirds have generally been so ineffective in biological control. In: Polgár L., Chambers L., Dixon A.F.G. \& Hodek I. (eds): Behaviour and Impact of Aphidophaga. SPB Publishing, The Hague, pp. 149-157.

Hemptinne J.-L., Dixon A.F.G. \& Cofin J. 1992: Attack strategy of ladybird beetles (Coccinellidae): factors shaping their numerical response. Oecologia 90: 238-245.

Hemptinne J.-L., Dixon A.F.G., Doucet J.-L. \& Petersen J.-E. 1993: Optimal foraging by hoverflies (Diptera: Syrphidae) and ladybirds (Coleoptera: Coccinellidae): Mechanisms. Eur. J. Entomol. 90: 451-455.

HoDEK I. 1960: The influence of various aphid species as food for the ladybirds Coccinella 7-punctata L. Ontogeny of Insects. Acta Symp. Praha 1959, pp. 314-316. 
IPERTI G. 1965: Contribution a l'étude de la specificité chez les principales Coccinelles aphidiphages des Alpes-Maritimes et des Basses-Alpes. Entomophaga 10: 159-178.

Janssen A., van Alphen J.J.M., Sabelis M.W. \& BaKKer K. 1995a: Odour-mediated avoidance of competition in Drosophila parasitoids: the ghost of competition. Oikos $\mathbf{7 3}$ : 356-366.

Janssen A., Alphen van J.J.M., Sabelis M.W. \& BaKker K 1995b: Specificity of odour mediated avoidance of competition in Drosophila parasitoids. Behav. Ecol. Sociobiol. 36: 229-235.

MARKS R.J. 1977: Laboratory studies of plant searching behaviour by Coccinella septempunctata L. larvae. Bull. Entomol. Res. 67: 235-241.

Mills N.J. 1982: Voracity, cannibalism and coccinellid predation. Ann. Appl. Biol., 101: 144-148.

RƯžIČKA Z. 1994: Oviposition-deterring pheromone in Chrysopa oculata (Neuroptera: Chrysopidae). Eur. J. Entomol. 91: 361-370.

RŮŽIČKA Z. 1996: Oviposition-deterring pheromone in chrysopids: Intra- and interspecific effects. Eur. J. Entomol. 93: $161-166$

RƯŽIČKA Z. 1997a: Persistence of the oviposition-deterring pheromone in Chrysopa oculata (Neur.: Chrysopidae). Entomophaga 42: 109-114.

RŮžIČKA Z. 1997b: Recognition of oviposition-deterring allomones by aphidophagous predators (Neuroptera: Chrysopidae, Coleoptera: Coccinellidae). Eur. J. Entomol. 94: 431-434.

RƯžIČKKA Z. 1998: Further evidence of oviposition-deterring allomone in chrysopids (Neuroptera: Chrysopidae). Eur. J. Entomol. 95: 35-39.
RŮŽǏČKA Z. \& HAVELKA J. 1998: Effects of oviposition-deterring pheromone and allomones on Aphidoletes aphidimyza (Diptera: Cecidomyiidae). Eur. J. Entomol. 95: 211-216.

Semyanov V.P. 1998: Leis dimidiata (Fabr.) (Coleoptera, Coccinellidae): biology and some results of using for control of aphids in greenhouses. In: Book of Abstracts, 6th Eur. Congr. Entomol. (Brunnhofer V. \& Soldán T. eds), České Budějovice, August 23-29, 1998, p. 585.

Sengonca C. \& Liu B. 1994: Responses of the different instar predator, Coccinella septempunctata L. (Coleoptera: Coccinellidae), to the kairomone produced by the prey and nonprey insects as well as the predator itself. Z. Pflkrankh. Pflschutz 101: 173-177.

ThIERY D. \& Gabel B. 1993: Inter-specific avoidance of eggassociated semiochemicals in four tortricids. Experientia 49: 998-1001.

Wratten S.D. 1973: The effectiveness of the coccinellid beetle Adalia bipunctata L. as a predator of the lime aphid Eucallipterus tiliae L. J. Anim. Ecol. 42: 785-802.

WRATTEN S.D. 1976: Searching by Adalia bipunctata L. (Col., Coccinellidae) and escape behaviour of its aphid and cicadellid prey on lime (Tilia vulgaris Hayne). Ecol. Entomol. 1: $139-142$.

YASUdA H., TAKagi T. \& Kogi K. 2000: Effects of conspecific and heterospecific larval tracks on the oviposition behaviour of the predatory ladybird, Harmonia axyridis (Coleoptera: Coccinellidae). Eur. J. Entomol. 97: 551-553.

ZELENÝ J. 1969: A biological and toxicological study of Cycloneda limbifer Casey (Coleoptera, Coccinellidae). Acta Entomol. Bohemoslov. 66: 333-344.

Received April 17, 2000; revised February 14, 2001; accepted April 4, 2001 